\title{
Streamflow, Suspended Solids, and Turbidity Characteristics of the Gin River, Sri Lanka
}

\author{
T. N. Wickramaarachchi, H. Ishidaira and T. M. N. Wijayaratna
}

\begin{abstract}
Human induced impacts on the river systems result in decrease in water quality, which is generally reflected by an increase of particulate matter in rivers. Turbidity and suspended solids are part of physical and aesthetic parameters and good indicators of other pollutants that are carried as sediment in suspension.

Study objectives were to define the relation between turbidity and total suspended solid (TSS) concentration in Gin river at Baddegama $\left(6^{\circ} 11^{\prime} 23^{\prime \prime} \mathrm{N}, 80^{\circ} 11^{\prime} 53^{\prime \prime} \mathrm{E}\right)$ in developing an estimation technique for TSS load, and to reveal how turbidity and TSS load vary with the streamflow. Linear regression model developed between turbidity and TSS concentration showed strong positive correlation $\left(\mathrm{R}^{2}=0.98\right)$. Results strongly suggest turbidity is a suitable monitoring parameter for TSS, where TSS evaluation is crucial when logistical and financial constraints make TSS sampling impractical. Mean daily TSS loads in the Gin river at Baddegama during 2000-2009 were modeled in the study using load-discharge rating curve for estimating constituent loads in rivers. Relatively strong relationship $\left(R^{2}=0.85\right)$ was observed between the rating curve estimated and observed TSS loads. Estimated TSS loads were having substantial temporal variation and generally peaked in May and October, coinciding with the high flows. Turbidity which ranged between 2.3 NTU (Nephelometric Turbidity Units) and 195 NTU significantly exceeded the maximum permissible limits of the water quality standards set for the potable water as well the inland waters of Sri Lanka. Since there was no specific water quality standards developed for TSS in Sri Lanka to compare with the present values, TSS concentrations were compared with the permissible total solid levels. TSS concentrations which ranged between $2.4 \mathrm{mg} / 1$ and $204 \mathrm{mg} / 1$ were well below the maximum permissible total solid level cited in the Sri Lanka standards for potable water. Understanding on this turbidity and TSS characteristics in Gin river flow might be useful for water managers and planners to adjust operations accordingly at water treatment plants.
\end{abstract}

Keywords: Linear regression, Load-discharge rating curve, Streamflow, Suspended solid, Turbidity

\section{Introduction}

Increasing population and industrialization have resulted in a variety of impacts on the river systems, while increasing the demand for higher quality water. Increased sediment and nutrient loading in rivers adversely affect the river water quality. Water quality and river flows are correlated and this correlation varies spatially as well as temporally. Turbidity is an optical property of a liquid that causes light rays to scatter and absorb rather than transmit in straight lines through the sample. Turbid water results from the presence of suspended and dissolved matter such as clay, silt, finely divided organic matter, plankton, other microscopic organisms, organic acids, and dyes [1]. Suspended sediment and turbidity are thought to increase with increasing stream size, stream order, and drainage area because of the accumulation of sediment and nutrients from the watershed and stream banks [2]. The level of suspended solids in rivers changes rapidly and unpredictably with changing water depths and velocities related to anthropogenic causes or natural hydrologic events making the quantification of suspended solids critical. To capture these rapid changes in suspended solids, sampling must be conducted at a high temporal frequency that is usually impractical and expensive. A more practical method is to monitor a surrogate, some parameter that is closely related to the concentration of

Eng. (Mrs) T. N. Wickramaarachchi, B.Sc. Eng(Hons)
(Moratuwa), MPhil (Moratuwa), MJSCE(Japan), AMIE(Sri
Lanka), Senior Lecturer, Department of Civil E Env. Engineering,
University of Ruhuna. (Currently reading for PhD)
Eng. (Dr) H. Ishidaira, B.Sc. Eng(Nagaoka), M.Eng (Nagaoka),
D.Eng (Nagaoka), Associate Professor, Interdis. Graduate School
of Medicine and Engineering, University of Yamanashi, Japan.
Eng. (Dr) T. M. N. Wijayaratna, B.Sc. Eng(Hons) (Moratuwa),
M.Eng (AIT), D.Eng (Yokohama), C.Eng, MIE(Sri Lanka), Senior
Lecturer, Department of Civil E Env. Eng., University of Ruhuna. 
suspended solid which can be continuously monitored $[3,4]$. Turbidity measurements are theoretically well correlated to suspended solid concentration because turbidity represents a measure of water clarity that is directly influenced by suspended solids. As such turbidity based estimation models typically are effective tools for generating suspended solid concentration data [5].The use of turbidity as a surrogate for suspended solid concentration has become more common and shown by several river basin studies around the world $[6$, $7,8,9,10]$.

Present study intends to assess the quality of water in Gin river because of its significance as the primary drinking water source for the Galle city. Gin river caters approximately $90 \%$ of the drinking water to Galle, the capital city in Southern Sri Lanka. Human activities in the Gin river basin have increased substantially in the past few decades including alterations in landuse pattern; subsequent to the expansion of homesteads, cultivated area in the basin has been decreased by $10 \%$ between early 80 s and late 90s [11]. These activities have been causing significant impacts on the quality and clarity of water in the river creating a need to monitor the quality of water. In spite of these activities, there remains a lack of comprehensive water quality analysis for the basin. Turbidity is a significant indicator of the quality of water. The correlation between TSS and turbidity is well documented for number of sites and turbidity has been utilized as less expensive and easiest to measure method enabling turbidity to serve as a surrogate for suspended solid. This study assessed how turbidity, as related to TSS, vary with Gin river flow at Baddegama. LOADEST, a load-discharge rating curve for estimating constituent loads in rivers is used in this study to develop regression model and estimate TSS load [12]. LOADEST is widely used to estimate constituent loads in rivers $[13,14,15,16,17,18]$.

Results of the study could be useful in monitoring turbidity levels to meet water quality standards, to prevent adverse effects on aquatic life, and to enhance aesthetic and recreational values. Moreover understanding on turbidity and TSS characteristics in river water assists in estimating real-time TSS based on automated turbidity record system.

\section{Study Area}

Gin river originates from the Gongala mountains in Deniyaya having an elevation of over $1300 \mathrm{~m}$ and flows to the Indian Ocean at Gintota in Galle district. Gin catchment is about $932 \mathrm{~km}^{2}$ and the catchment area at Baddegama river gauging station is $780 \mathrm{~km}^{2}$. The catchment is located approximately between longitudes $80^{\circ} 08^{\prime \prime} \mathrm{E}$ and $80^{\circ} 40^{\prime \prime} \mathrm{E}$, and latitudes $6^{\circ} 04^{\prime \prime} \mathrm{N}$ and $6^{\circ} 30^{\prime \prime} \mathrm{N}$ and includes Galle $(83 \%$ of the basin area), Matara ( $9 \%$ of the basin area), Rathnapura ( $7 \%$ of the basin area), and Kalutara ( $1 \%$ of the basin area) administrative districts. The catchment's land is primarily used for human settlements, agriculture, natural forests and plantation forests [11]. Rainfall pattern in the catchment is of bi-modal, falling between May and September (Southwest monsoon, which is the major rainfall season), and again between November and February (Northeast monsoon) followed by the intermonsoon rains during the remaining months of the year. Rainfall varies with altitude with mean annual rainfall above $3500 \mathrm{~mm}$ in the upper reaches to less than $2500 \mathrm{~mm}$ in the lower reaches of the catchment. Gin river annually discharges about 1268 million cubic meters (MCM) of water to sea [19]. It is the primary drinking water source, from which pipe-borne water is supplied to Galle city, the capital of Southern Sri Lanka, averaging 0.7 MCM per month. Gin river, its catchment location, and Baddegama river gauging station are shown in Figure 1.

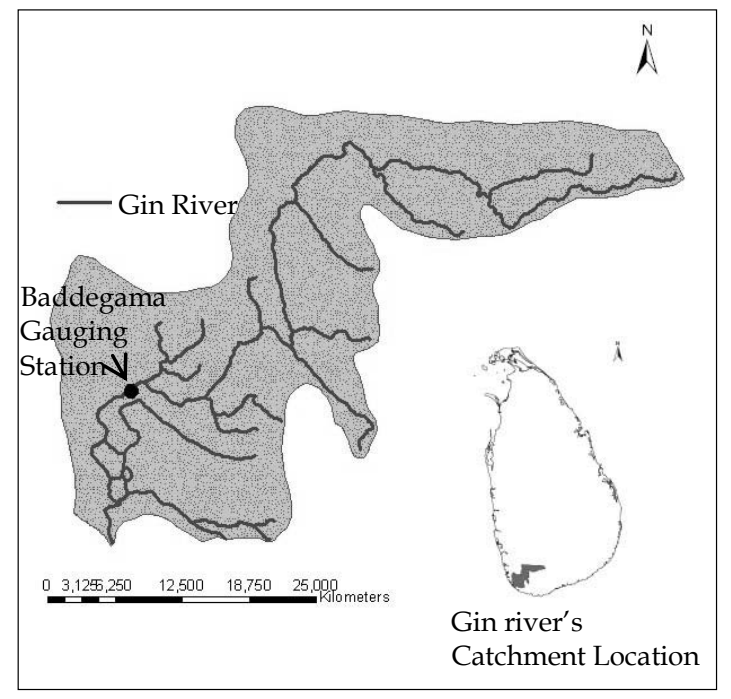

Figure 1- Gin river, its catchment location, and Baddegama river gauging station. 


\section{Data and Analysis}

\subsection{Turbidity and TSS Correlation}

Turbidity is influenced by color, temperature, and shape of the suspended particles. Turbidity-TSS relationships have been reported, on site by site basis, and the reliability varies due to water color and suspended particle composition [20]. A direct correlation between turbidity and suspended solid concentration has been documented in many studies conducted around the world. Moreover the magnitude of turbidity in streams, lakes, and estuaries is often proportional to suspended solid concentration and the turbidity-suspended solid concentration relation has been quantified through linear regression analysis in number of studies $[7,8$, $21,22,23,24]$. In addition, as one of the least expensive and easiest to measure methods, turbidity has been utilized to determine TSS concentration in the present study.

Turbidity was measured on more than 100 samples collected over three months period at Baddegama (6 $\left.6^{\circ} 11^{\prime} 23^{\prime \prime} \mathrm{N}, 80^{\circ} 11^{\prime} 53^{\prime \prime} \mathrm{E}\right)$ and TSS concentration of the same samples were analyzed as per standard procedures [25]. This sampling effort over wide range of turbidity values, provided data for the development of regression equation to estimate TSS concentration from the turbidity. As a means of quality assurance, approximately $20 \%$ of the total number of samples were collected as duplicate samples and analyzed to determine the precision of the results. Almost

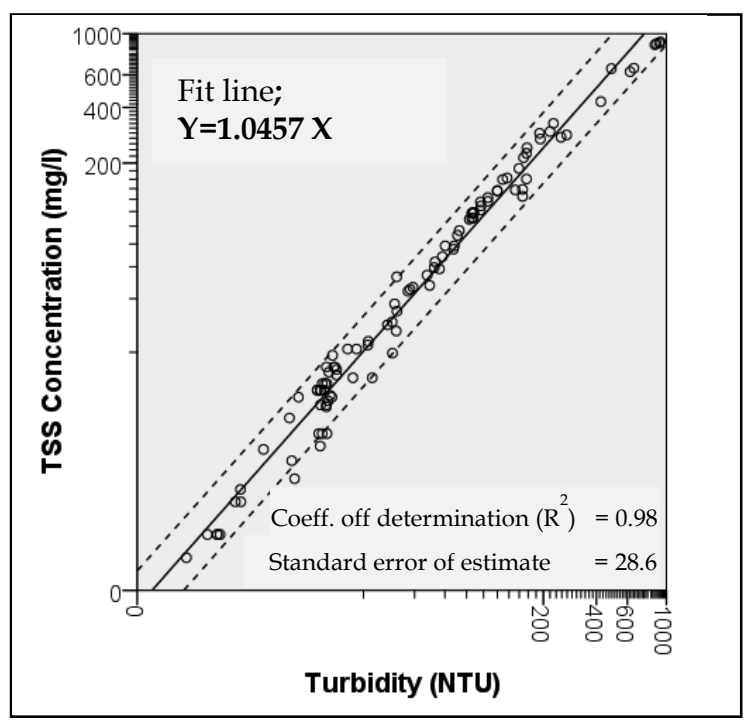

Figure 2 - Linear regression of turbidity and TSS concentration including 95\% prediction intervals (number of samples $=103$ ). all duplicate TSS concentrations were within $5 \%$ of the corresponding sample TSS concentrations. Relationship between turbidity and TSS concentration was assessed using the regression analysis with $95 \%$ prediction interval. Linear regression equation was developed using the least squares method. A strong $\left(R^{2}=0.98\right)$ highly significant $(p<0.0001)$ relationship existed between turbidity and TSS concentration (Figure 2).

Figure 2 shows the regression best fit line bounded by $95 \%$ prediction intervals. Data fairly fit around the regression line and the model provides reasonably accurate prediction; for Gin river's long term mean turbidity value of $25.2 \mathrm{NTU}$, the measured TSS concentration is $26 \mathrm{mg} / \mathrm{l}$, and the model yields a TSS concentration of $26.4 \mathrm{mg} / 1$ with a $95 \%$ confidence interval from $25.7 \mathrm{mg} / 1$ to 27.0 $\mathrm{mg} / \mathrm{l}$.

Regression models developed between turbidity and TSS concentration in most of the previous studies have shown similarity to the present study, based on the fact that the regression line passing through the origin. Slope coefficients in the regression models developed previously have been ranging between $0.9-1.3$, producing comparable results to the present study. Variability of the slope coefficient from one study to another is attributed to the characteristics of suspended sediments and their transport processes in the catchment; high turbidity subsequent to fine suspended particles but low TSS concentration results in lower slope coefficient and vise versa. These acknowledge similar nature of the regression models that best describe turbidity TSS relationship though depend upon catchment land use and the associated hydrologic responses in the catchment.

\subsection{TSS Load Model Development}

Turbidity data of 116 water quality samples at Baddegama $\left(6^{\circ} 11^{\prime} 23^{\prime \prime} \mathrm{N}, 80^{\circ} 11^{\prime} 53^{\prime \prime} \mathrm{E}\right)$ tested at monthly frequency between February 2000 and November 2009 were obtained from the National Water Supply and Drainage Board (Southern), Sri Lanka. Sampling location of Baddegama is located near the streamflow gauging station maintained by the Department of Irrigation, Sri Lanka. Daily streamflow data at the Baddegama gauging station for the same period were collected from the Department of Irrigation. Water quality and streamflow data collected on a particular day are representative 
of average concentration and average flow on that day, respectively.

Using the linear regression equation developed, the corresponding TSS concentrations were calculated for the 116 turbidity measurements. The calculated TSS concentrations were used to estimate daily and monthly suspended solid loads. Load-discharge rating curve [12] for estimating constituent loads in rivers incorporated into the LOADEST, a computer programme developed by the United States Geological Survey (USGS) was used in this study to develop multiple regression model and estimate TSS loads over the period 2000 2009. LOADEST uses time series streamflow data and constituent concentrations to develop and calibrate regression model that describes constituent loads in terms of various functions of streamflow and time. The calibrated model is then used to estimate constituent loads using daily streamflow observations over specified time period.

The calibration and estimation procedures within LOADEST are based on three statistical methods; Adjusted Maximum Likelihood Estimation (AMLE), Maximum Likelihood Estimation (MLE), and Least Absolute Deviation (LAD). AMLE and MLE methods are appropriate when the calibration model residuals (errors) are normally distributed and AMLE is the method of choice when the calibration data set contains censored data (constituent concentrations that are less than the laboratory detection limit). LAD is an alternative method to maximum likelihood estimation when the residuals are not normally distributed. For the special case where the calibration data set is uncensored, the AMLE method converges to MLE, resulting in a minimum variance unbiased estimate of constituent loads [26]. Since all the data sets used in this study were uncensored, model coefficients for the AMLE and MLE methods were identical and the AMLE was used to determine the model coefficients and estimate the log load. Two statistics, the Akaike Information Criterion (AIC) and the Schwarz Posterior Probability Criterion, were computed for the calibrated model $[12,27]$.

In this study, a regression model was developed and calibrated in estimating the TSS loads. TSS concentrations were used in conjunction with corresponding observed streamflow data to develop and calibrate the regression model using AMLE. The model with the lowest value of the AIC was then selected for use in load estimation. The regression model developed for TSS using LOADEST is shown in Table 1.

AMLE results are contingent upon the assumption that model residuals are normally distributed. Once the model formulation and calibration were done, AMLE residuals were examined to see whether this assumption was valid. Checks for normality included construction of a normal probability plot, a plot of model residuals versus their Z-scores, which should yield a normal probability plot [12, 29].The linearity of the plot suggested that the residuals follow a normal distribution (Figure 3). This linearity was supported by the Probability Plot Correlation Coefficient (PPCC) of 0.97 .

Coefficient of determination $\left(R^{2}\right)$ of the regression model for TSS load which represents fraction of the variance explained by regression is shown in Table 1 . The relatively high $R^{2}$ value indicated that the model successfully simulated the variability in constituent loads.

Table 1 - Regression model developed for TSS using LOADEST and the coefficient of determination $\left(R^{2}\right)$.

\begin{tabular}{|c|c|c|c|c|c|c|c|c|}
\hline \multirow{2}{*}{ Regression model } & \multicolumn{7}{|c|}{ Model Coefficients (a) } & \multirow[t]{2}{*}{$R^{2}$} \\
\hline & $\mathrm{a} 0$ & a1 & $\mathrm{a} 2$ & a3 & $\mathrm{a} 4$ & a5 & a6 & \\
\hline $\begin{array}{l}\operatorname{Ln}(\mathrm{L})=\mathrm{a} 0+\mathrm{a} 1 \operatorname{LnQ}+\mathrm{a} 2 \operatorname{LnQ}^{2}+\mathrm{a} 3 \operatorname{Sin}(2 \pi \mathrm{T}) \\
+\mathrm{a} 4 \operatorname{Cos}(2 \pi \mathrm{T})+\mathrm{a} 5 \mathrm{~T}+\mathrm{a} 6 \mathrm{~T}^{2}\end{array}$ & $\begin{array}{l}10.88 \\
(0.1)\end{array}$ & $\begin{array}{l}1.69 \\
(0.07)\end{array}$ & $\begin{array}{l}-0.08 \\
(0.07)\end{array}$ & $\begin{array}{l}0.03 \\
(0.08)\end{array}$ & $\begin{array}{l}0.30 \\
(0.08)\end{array}$ & $\begin{array}{l}-0.02 \\
(0.02)\end{array}$ & $\begin{array}{l}0.02 \\
(0.01)\end{array}$ & 0.85 \\
\hline
\end{tabular}

Notes:

(a) Standard deviation of the model coefficients are shown in parentheses.

$\mathrm{L}$ is the constituent load; $\mathrm{Q}$ is the streamflow; $R^{2}$ is the coefficient of determination for the regression model.

Relationships are considered to be significant at $\mathrm{p}<0.05$.

$\mathrm{LnQ}=\mathrm{Ln}($ streamflow $)$ - center of $\operatorname{Ln}($ streamflow); $\mathrm{T}=$ decimal time - center of decimal time.

Explanatory variables were centered to eliminate the colinearity $[12,28]$. 


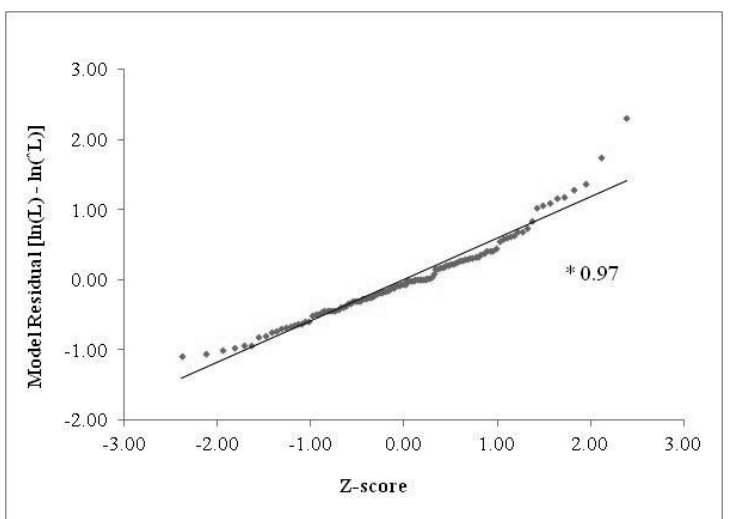

Figure 3 - Normal probability plot for the model residuals of the AMLE regression.

Notes:

Model Residual $\left[\ln (\mathrm{L})-\ln \left({ }^{\wedge} \mathrm{L}\right)\right]$ is the difference between the observed and estimated values of $\log$ load

$\mathrm{L}$ is in kilograms per day.

* PPCC

\section{4. $\quad$ Results \& Discussion}

4.1 Influence of Stream Flow on Turbidity

Turbidity is an indicator of the amount of sediment and related constituents transported by a stream. According to Christensen et al. [30], turbidity and streamflow are related because streamflow can affect suspension of the sediment and related constituents. But the conditions between turbidity and streamflow affect this relation; Paustian \& Beschta [31] have revealed that, first storm flow occurring after a dry period, results in higher turbidity than from subsequent larger flows due to an initial flush of suspended sediment. In Gin river, turbidity varies directly with the streamflow (Figure 4).

A plot of turbidity vs. streamflow exceedance

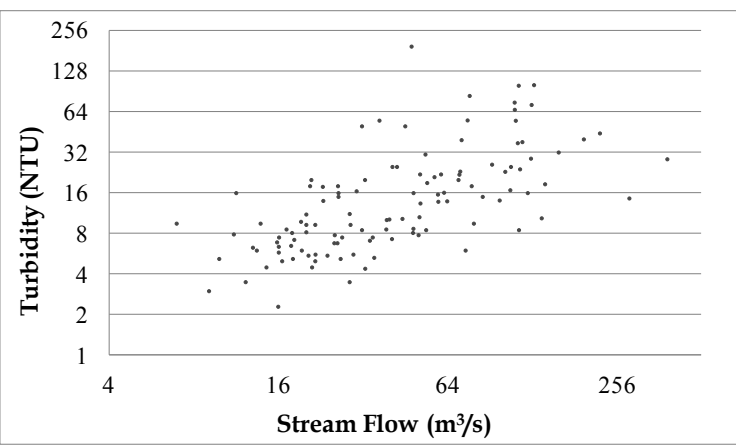

Figure 4 - Variation in turbidity with the streamflow (2000-2009).

probability shows that higher turbidity values are in the range of intermediate and higher flows (Figure 5). During all the flow regimes, turbidity levels indicated exceedance of the water quality standards set for the potable water as well the inland waters of Sri Lanka. In $92 \%$ of the samples, turbidity level exceeded 5 NTU, the maximum permissible limit for Class 1 Waters; drinking water with simple treatment, in the proposed ambient water quality standard for inland waters of Sri Lanka [32]. $8 \mathrm{NTU}$, the maximum permissible limit for Sri Lanka standards for potable water [33] has been exceeded by $70 \%$ of the samples. Sediments from catchment runoff subsequent to higher rainfall, eroding stream banks, and sand mining activities might be attributable to the high levels of turbidity.

\subsection{TSS Load Estimation}

TSS concentration values derived from the turbidity based linear regression equation were used as the model input concentration data to develop TSS load-discharge multiple regression model using the LOADEST program. TSS mean load estimates were developed on daily and monthly basis from January 2000 to December 2009.

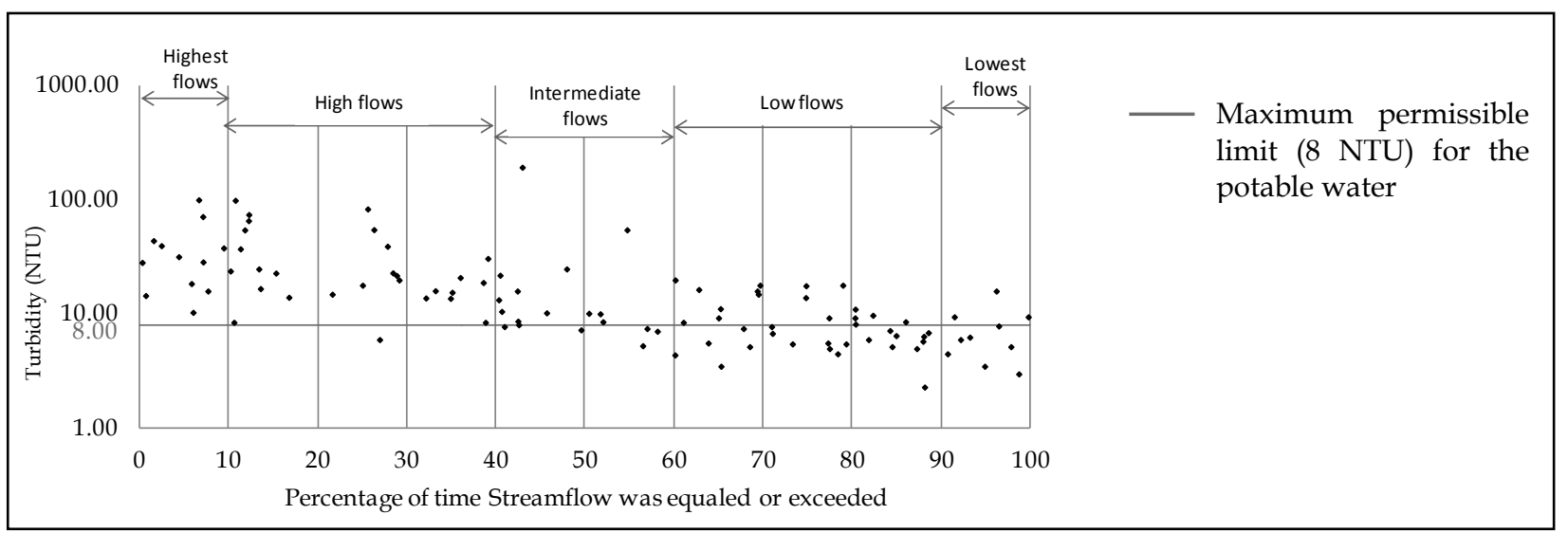

Figure 5 - Turbidity vs. streamflow exceedance probability (2000-2009). 
Model input TSS loads were plotted against the estimated TSS loads by the LOADEST to evaluate the fitness of the regression model developed (Figure 6). 1:1 line represents similar values for both model input and model estimated. Points were moderately scattered near the 1:1 line over a wide range of loads. More points clustered slightly below the 1:1 line indicated slight underestimation of the model predicted loads.

\subsection{Variation in TSS with Streamflow}

It is important in any suspended sediment estimation study to collect samples over several years and over a wide range of streamflows to more accurately depict the sediment flux under all flow regimes [22]. Figure 7 illustrates the

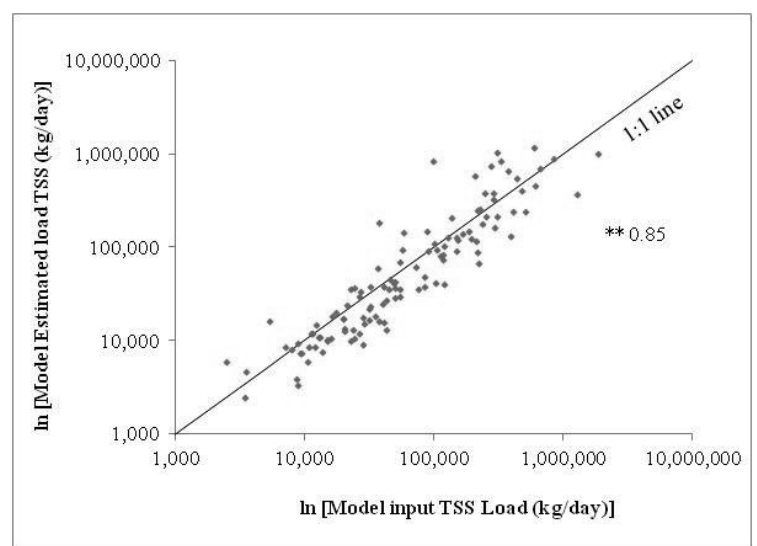

Figure 6 - Relationship between model input TSS loads and model estimated TSS loads.

Note:

** $R^{2}$ for the regression model.

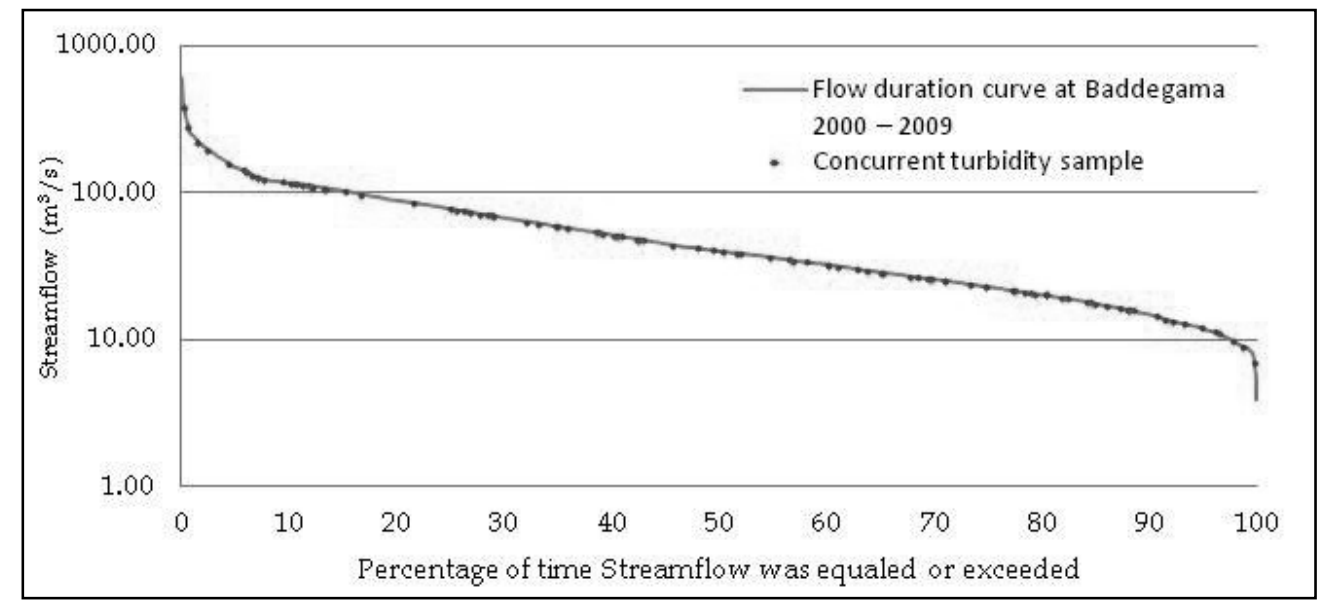

Figure 7 - Flow duration curve and concurrent turbidity sampling.

relation of the streamflow, at which the turbidity samples were collected during February 2000 - November 2009, to flow duration, based on the streamflow data at Baddegama station. Distribution of sample collection over such a wide range in the streamflow hydrograph, particularly at the high flows, indicates that the TSS concentration data would characterize TSS load information for most flow and turbidity conditions.

TSS concentrations were compared with the permissible total solid levels, since there was no specific water quality standards developed for TSS in Sri Lanka. TSS concentrations which ranged between $2.4 \mathrm{mg} / 1$ and $204 \mathrm{mg} / 1$ were well below the maximum permissible total solid level $(2000 \mathrm{mg} / \mathrm{l})$ cited in the Sri Lanka standards for potable water [33].

Concentration of TSS in rivers increases as a function of flow. TSS concentrations have been shown to be strongly correlated with the streamflow with most of the sediment load transported during peak flow events [34, 35, 36]. The relationship between streamflow and TSS load is well established for Gin river (Figure 8). High TSS loads occur in May and October with the corresponding peak flows in the Gin river. This peak constituent load occurrence in Gin river in coinciding with the high flows is further supported by Wickramaarachchi et al. [18]. When considering annual TSS loads in Gin river, there was a

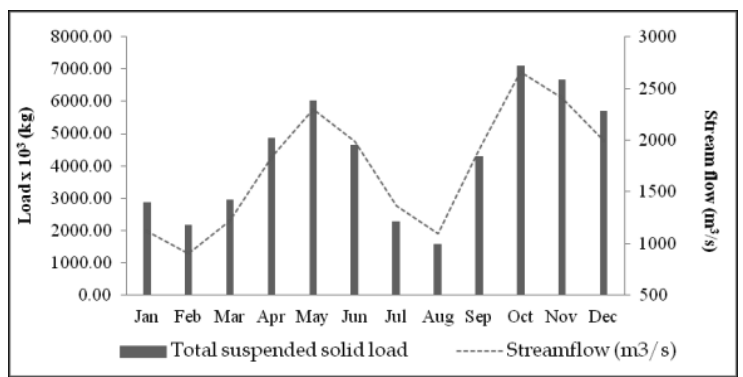

Figure 8 - Mean monthly TSS load estimate and mean monthly streamflow of Gin River at Baddegama during 2000-2009. 


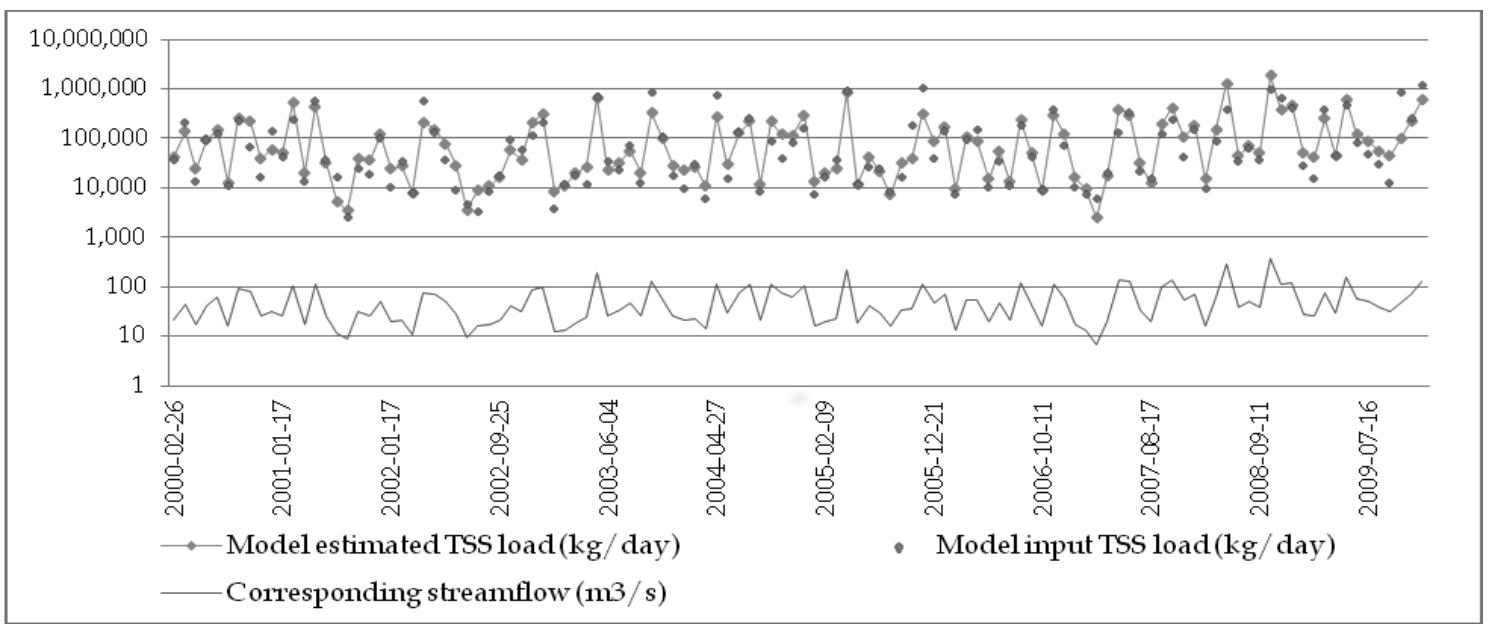

Figure 9 - Relation of model input to model estimated TSS loads and corresponding streamflow during 2000-2009.

decreasing trend $(0.02 \%)$ in annual TSS loads and the trend was statistically significant at the $95 \%$ confidence level $(p<0.05)$.

Figure 9 shows the model input and model estimated average daily TSS loads during 2000-2009. The estimated TSS loads closely resemble the model input TSS loads, particularly at the moderate flows, although some estimated loads during extreme flow conditions have some deviations. On the descending limbs of the hydrograph, model input loads are slightly overestimated by the model. As Clark [37] pointed out, the reason might be that the samples collected during the ascending limb and near the peak of the hydrograph typically contained higher concentrations of solids than did samples collected during the descending limb at the same discharge. This is because material that had accumulated in the stream prior to storm runoff becomes mobile as stream velocities rise and the concentrations measured later at the same discharge were low because the stream had been flushed of accumulated solids. However, the model does not account for this and as a result, changes in load resulting from rapid changes in streamflow may not be modeled accurately.

\section{Conclusions}

Correlation established between the turbidity and TSS concentration in Gin river at Baddegama can be used to compute TSS concentrations beyond the period of record used in model development with proper sample collection and analysis. Moreover the understanding on turbidity and TSS characteristics in river water might be useful in exploring the potential to establish automated turbidity recording system that makes real-time sampling decisions to facilitate TSS estimation in Gin river at Baddegama.

Due to the overall fitness reflected by the loaddischarge regression model developed for TSS load estimation, it could be utilized in inferring the TSS loads from the flow data, during unsampled periods.

Results of the study could be used to better understand the fluctuation of turbidity and TSS under changing flow regimes and to assess quality of water in Gin river relative to the water quality standards in practice. This prevailing water quality conditions in Gin river provide necessary information for water managers and planners to adjust water treatment strategies accordingly.

\section{Acknowledgements}

Authors gratefully acknowledge National Water Supply and Drainage Board (Southern), Sri Lanka for providing the water quality data of Gin river and facilitating the water quality testing. Sincere appreciation is extended to University of Yamanashi, Japan and JSPS (Japan Society for Promotion of Science) for the technical and financial support for the study. 


\section{References}

1. ASTM International, D4410, Terminology for fluvial sediment, Annual book of standards, Water and Environmental Technology: West Conshohocken, Pennsylvania, 2007, 7 p.

2. Thorp, J. H., Thomas, M. C., \& Delong, M. D., "The Riverine Ecosystem Synthesis: Biocomplexity in River Networks Across Space and Time", River Res. Appl., Vol. 22, No. 2, 2006, pp. 123-147.

3. Leopold, L. B., Maddock, T., The hydraulic geometry of stream channels and some physiographic implications, U.S. Geological Survey Professional Paper 252, 1953, 57 p.

4. Susfalk, R. B., Fitzgerald, B., \& Knust, A. M., Characterization of Turbidity and Total Suspended Solids in the Upper Carson River, Nevada, Desert Research Institute (DRI), DHS Publication No. 41242, 2008.

5. Jastram, J. D., Moyer, D. L., \& Hyer, K. E., A Comparison of Turbidity-based and StreamflowBased Estimates of Suspended-Sediment Concentrations in three Chesapeake Bay tributaries, U.S. Geological Survey Scientific Investigations Report 2009-5165, 2009, 37 p.

6. Gippel, C. J., “The Use of Turbidity Instruments to Measure Stream Water Suspended Sediments Concentration", Department of Geography and Oceanography, University College, Australian Defense Force Academy. Monograph Series No. 4, 1989.

7. Lewis, J., “Turbidity-Controlled Suspended Sediment Sampling for Runoff-event Load Estimation", Water Resour. Res., Vol. 32, No. 7, 1996, pp. 2299-2310.

8. Christensen, V. G., Xiaodong, J., \& Ziegler, A. C., Regression analysis and real-time water-quality monitoring to estimate constituent concentrations, loads, and yields in the Little Arkansas River, southcentral Kansas, 1995-99, U.S. Geological Survey Water-Resources Investigations, 2000.

9. Smolen, K. D., “Trout Creek Stream Restoration and Wildlife Enhancement Project: Water Quality Monitoring", M.S. Thesis, Graduate Program of Hydrologic Sciences, University of Nevada, Reno, 2004, 134 p.

10. Daphne, L. H. X., Utomo, H. D., \& Kenneth, L.Z.H., "Correlation between Turbidity and Total Suspended Solids in Singapore Rivers", Journal of Water Sustainability, Vol. 1, No. 3, 2011, pp. 313-322.

11. Wickramaarachchi, T. N., Ishidaira, H., \& Wijayaratna, T. M. N., "Projecting Land use Transitions in the Gin Catchment, Sri Lanka",
Res. J. Environ. Earth Sci., Maxwell publishers, in press (Accepted for publication June 2013).

12. Runkel, R. L., Crawford, C. G., \& Cohn, T. A., Load Estimator (LOADEST): A FORTRAN program for estimating constituent loads in streams and rivers, U.S. Geological Survey Techniques and Methods, book 4, chap. A5, 2004, 69 p.

13. Hooper, R. P., Aulenbach, B. T., \& Kelly, V. J., "The National Stream Quality Accounting Network: A Flux-Based Approach to Monitoring the Water Quality of Large Rivers", Hydrol. Process., Vol. 15, No. 7, 2001, pp. 1089-1106.

14. Aulenbach B. T., Annual Dissolved Nitrate Plus Nitrite and Total Phosphorus Loads for the Susquehanna, St. Lawrence, Mississippi-Atchafalaya and Columbia River Basins for 1968 to 2004, Open File Report 2006-1087, US Geological Survey, Reston, VA, 2006.

15. Morrison, J., Colombo, M. J., Surface-water quality and nutrient loads in the Nepaug Reservoir watershed, northwestern Connecticut, 1999-2001, U.S. Geological Survey Scientific Investigations Report 2006-5272, 2006, 36p.

16. Foster, K., Kenney, T. A., Dissolved-solids load in Henrys Fork upstream from the confluence with Antelope Wash, Wyoming, water years 1970-2009, U.S. Geological Survey Scientific Investigations Report 2010-5048, 2010, 16p.

17. Stenback, G. A., Crumpton, W. G., Schilling, K. E., \& Helmers, M. J., "Rating Curve Estimation of Nutrient Loads in Iowa Rivers", J. Hydrol., Vol. 396, No. 1-2, 2011, pp. 158-169.

18. Wickramaarachchi, T. N., Ishidaira, H., \& Wijayaratna, T. M. N., "Variation of Constituent Loads and Concentrations with the Flow in Gin River, Sri Lanka", J. Natl. Sci. Found. Sri Lanka, in press (Accepted for publication June 2013).

19. National Atlas, $2^{\text {nd }}$ ed., Survey Department of Sri Lanka, 2011.

20. Packman, J. J., Comings, K. J., \& Booth, D. B., "Using Turbidity to Determine Total Suspended Solids in Urbanizing Streams in the Puget Lowlands", Confronting Uncertainty: Managing Change in Water Resources and the Environment, Canadian Water Resources Association annual meeting, Vancouver, BC, 27-29 October 1999, 1999, pp. 158-165.

21. Gilvear, D. J., Petts, G.E., “Turbidity and Suspended Solids Variations Downstream of a Regulating Reservoir", Earth Surf. Process. Landf., Vol. 10, No. 4, 1985, pp. 363-373.

22. Uhrich, M. A., Bragg, H. M., Monitoring instream Turbidity to Estimate Continuous SuspendedSediment loads and yields and clay-water volumes in 
the Upper North Santiam River Basin, Oregon, 1998-2000, U.S. Geological Survey WaterResources Investigations Report 03-4098, 2003, $43 \mathrm{p}$.

23. Rasmussen, P. P., Gray, J. R., Glysson, G. D., \& Ziegler, A.C., Guidelines and procedures for computing time-series suspended-sediment concentrations and loads from in-stream turbiditysensor and streamflow data, U.S. Geological Survey Techniques and Methods, book 3, chap. C4, 2009, 52 p.

24. Ellison, C. A., Kiesling, R. L., \& Fallon, J. D., "Correlating Streamflow, Turbidity and Suspended Sediment Concentration in Minnesota's Wild Rice river", 2nd Joint Federal Interagency Conference, Las Vegas, NV, June 27 July 1, 2010.

25. Standard Methods for the Examination of Water and Wastewater, 21 ${ }^{\text {st }}$ ed., Eds: Eaton, A. D., Clesceri L. S., Rice E. W. \& Greenberg A. E., Washington D.C., published jointly by the American Public Health Association, the American Water Works Association and the Water Environment Federation, 2005.

26. Cohn, T. A., Gilroy, E. J., \& Baier, W. G., "Estimating Fluvial Transport of Trace Constituents using a Regression Model with Data Subject to Censoring", Proceedings of the Joint Statistical Meeting, Boston, 9-13 August, 1992, pp. 142-151.

27. Judge, G. G., Hill, R. C., Griffiths, W. E., Lutkepohl, H., \& Lee, T. C., Introduction to the theory and practice of econometrics, $2^{\text {nd }}$ ed.,John Wiley, New York, 1988, pp. 1024.

28. Cohn, T. A., Caulder, D. L., Gilroy, E. J., Zynjuk, L. D., \& Summers, R. M, "The Validity of a Simple Statistical Model for Estimating Fluvial Constituent Loads - An Empirical Study Involving Nutrient Loads Entering Chesapeake Bay", Water Resour. Res., Vol. 28, No. 09, 1992, pp. 2353-2363.

29. Helsel, D. R., Hirsch, R. M., Statistical methods in water resources, U.S. Geological Survey Techniques of Water-Resources Investigations, book 4, chapt. A3, 2002.

30. Christensen, V. G., Ziegler A. C., \& Jian X., "Continuous Turbidity Monitoring and Regression Analysis to Estimate Total Suspended Solids and Fecal Coliform Bacteria Loads in Real Time", Proceedings of the Seventh Federal Interagency Sedimentation Conference, March 25-29, 2001, Reno, NV. Subcommittee on Sedimentation, vol 1, 2001, pp III-94 to III-101.

31. Paustian, S. J., Beschta, R. L., "The Suspended Sediment Regime of an Oregon Coast Range
Stream", Water Resour. Bull., Vol. 15, 1979, pp. 144-154.

32. Proposed ambient water quality standards for inland waters of Sri Lanka, Central Environmental Authority, Sri Lanka, 2001.

33. Sri Lanka Standards for potable water - SLS 614, Sri Lanka Standards Institute, 1983.

34. Leopold, L. B., Wolman M. G., \& Miller, J. P., Fluvial processes in geomorphology, San Francisco, CA, Freeman, 1964.

35. Allan, J. D., Stream ecology: Structure and function of running waters. London: Chapman and Hall, 1995.

36. Doyle, M. W., Stanley, E. H., Strayer, D. L., Jacobson, R. B., \& Schmidt, J. C., "Effective Discharge Analysis of Ecological Processes in Streams", Water Resour. Res., Vol. 41(W11411), 2011, 16 p.

37. Clark G. M., Occurrence and transport of cadmium, lead, and zinc in the Spokane River Basin, Idaho and Washington, water years 1999-2001, U.S. Geological Survey Water-Resources Investigations Report 02-4183, 2003, pp. 37. 